\title{
The DART Perspective on Value Co-Creation between Frontline Employees and Internal Service Providers
}

\author{
Raymond Nagarethenam, Amjad Shamim* and Zulkipli Ghazali \\ Department of Management \& Humanities, Universiti Teknologi PETRONAS, 32610 Seri Iskandar, \\ Perak, Malaysia
}

\begin{abstract}
This article studies the DART model and its importance in developing actors value co-creation attitude and behavior within the firms' micro-level ecosystem. Fifteen propositions are proposed based on the literature from service-dominant logic perspective. Two major contributions are made. First, the article provides the importance and need of co-creation between the actors such as frontline employees with internal service providers in firms' micro-level ecosystem. Second, it highlights the dialogue, access, risk and transparency as important factors that can develop actors' attitude towards engagement in co-creation which subsequently lead to actors' actual engagement in co-creation. The article is conceptual and needs empirical validation.
\end{abstract}

Keywords: Service-dominant logic, service eco-system, value co-creation

\section{Introduction}

The frontline employees (FLEs) are the primary actors that often interact with the customers and play a crucial role in value co-creation. They are the point of contact between an organization and its consumers and facilitate the value co-creation process in a more informed way during the service provision (Singh, Brady, Arnold, \& Brown, 2016). While past research has much focused on the FLEs engagement in value co-creation with customers, little attention is given to the value co-creation between FLEs and Internal Service Providers (ISPs). The ISPs here referred as the employees from all other departments within the organization that provide service to the FLEs. As the Service-Dominant Logic (SDL) perspective reveals that value is created by multiple actors through integration and exchange the resources in a shared network (Stephen L Vargo, Akaka, \& Vaughan, 2017), hence the value co-creation is equally important among internal actors which are the part of firms' micro-level ecosystem. This paper, therefore, takes the firms' micro-level ecosystem as one of the important perspectives where FLEs engagement in value co-creation with ISPs is crucial which subsequently can influence their value co-creation process with customers.

\footnotetext{
* Corresponding author: amjadshamim@gmail.com
} 
To practice the value co-creation at micro-level within the firms' internal environment, the four building blocks of interaction such as dialogue, access, risk-assessment, and transparency (most commonly known as DART Model) seem crucial (Prahalad and Ramaswamy, 2004). This paper proposes that the dialogue, access, risk-assessment, and transparency between ISPs and FLEs can be significant drivers for the FLEs to engagement in co-creation with ISPs that can further affect their value co-creation process with customers. The co-created value at micro-level would affect the meso and macro-level eco-system. The following sections provide the detailed explanation of the link between four building blocks and FLEs engagement in value co-creation.

\section{Literature Review}

\subsection{Building Blocks of Interaction - DART Model}

The emerging concept of service-dominant logic (SDL) (Stephen L. Vargo \& Lusch, 2004) was the basis of another fundamental element of the theoretical background to the building blocks of interaction (Prahalad \& Ramaswamy, 2004b). The SDL perspective defines value creation differently than it was perceived in the goods-dominant logic. According to SDL, the value cannot be embedded in the product or distribution process, rather it is co-created with the customers (Stephen L. Vargo \& Lusch, 2007). The Prahalad and Ramaswamy (2004) proposed the DART model which is useful to conceptualize co-creation processes and to comprehend the customer behavioural and cognitive processes. This model remains as the most popular framework to guide the implementation of value co-creation (Mazur \& Zaborek, 2014). Hence, the need to further explore the DART model particularly on the conceptual and quantitative study was recommended (Mazur \& Zaborek, 2014)

The dialogue is the deep engagement, live interactivity, understanding and a willingness on common agreement by both parties (Albinsson, Perera, \& Sautter, 2015). The dialogue between the FLEs and ISPs are essential. For instance, when both parties engage in a dialogue, the feedbacks relating to the service provision can be shared between the actors that leads to the co-creation of value. Hence, to practice co-creation within the organization ecosystem, open dialogue between the actors is necessary. However, it is difficult to manifest the value co-creation without the ability to access information. The access from the building blocks point of view referred to the frontline employees to have immediate and timely access to internal service providers and resources that can facilitate the exchange of information (Albinsson et al., 2015). This indicates that the internal service provider needs to assist the frontline employees when it is necessary by providing all kind of information and support. The access should be given at all stages of the process, starting from designing to the experience. Else, the co-creation is ineffective in the event that the frontline employees are unable to access the critical information about the products and/or services (Schiavone, Metallo, \& Agrifoglio, 2014). The access enhances the feelings of equity among the frontline employees (Solakis, Peña-Vinces, \& Lopéz-Bonilla, 2017), hence they feel more empowered and would prove better co-creators.

For FLEs to engage in co-creation, they would also require evidence on the risks associated with the production, delivery, and consumption of services and products. The awareness of risks facilitates FLEs in further service provision to the consumers in a better and secure way. This is referred to as risk-assessment. The risk-assessment is the provision of information about costs and benefits, and facilitate the informed decisions on the risks pertaining to co-creation (Albinsson et al., 2015). From a company-centric view, an organization is accountable for the risks related to the product offering (Ramaswamy, 2005). In the customer-centric view, the organizations should have a responsibility to notify the 
customers of the potential risks relating to the services and/or products. Thus, such an obligation is passed on to the frontline employees to caution the consumers of the risk relating to their desired products (Ramaswamy, 2005). Nevertheless, all these aspects can only be practiced if the transparency exists between the ISPs and FLEs. The transparency is an organization's information on value co-creation process which enhances the consumers' readiness to accept its products and services. Hence, the organizations should take the initiatives to update the business-related information such as by revealing necessary information to the FLEs to ensure transparency while providing service to the customers. By considering the importance of four building blocks in value co-creation, this research proposes that the dialogue, access, risk, and transparency leads to FLEs attitude towards value co-creation which subsequently develop their value co-creation behavior. Following sections further provide the detail of the association between four building blocks and FLEs value cocreation attitude and behavior.

\subsection{The practice of DART creates Actors Value Co-Creation Attitude}

The continuous practice of DART at firms' micro-level ecosystem can develop actors value co-creation attitude. The value co-creation attitude is predominantly based on the constructive theory of attitude formation based on the contextual nature of value co-creation ( Shamim, Ghazali, \& Albinsson, 2016). The actors (FLEs and ISPs in this case) value cocreation attitude is the tendency of actors to engage in interaction for mutual value creation. The value co-creation attitudes have three dimensions namely interaction attitude, knowledge sharing attitude, and responsive attitude (Shamim, Ghazali, \& Albinsson, 2017). In the context of micro-level eco-system, the interaction attitude is the willingness of the actors to engage in co-creation. The four building blocks of interaction are practiced at the micro-level ecosystem, this could lead to value co-creation attitude. Hence, we develop the following propositions:

\section{Proposition 1a: The dialogue between FLEs and ISPs develop their interaction attitude}

Proposition 1b: The access to resources between FLEs and ISPs develop their interaction attitude

\section{Proposition 1c: The risk-assessment between FLEs and ISPs develop their interaction attitude}

\section{Proposition 1d: The transparency between FLEs and ISPs develop their interaction attitude}

The knowledge sharing attitude is the willingness of FLEs and ISPs to share knowledge through continuous interaction for mutual value creation. The practice of four building blocks would give an opportunity to these actors to continuously share knowledge about their business practices. For instance, the FLEs must be trained in product knowledge as they have to further deliver this knowledge to the customers. The FLEs are mainly the custodians of market knowledge and customers knowledge which further needs to be shared with ISPs. The ISPs can get deep insight based on that knowledge, hence can develop better service which not only creates value for FLEs but also for the customers. Hence, the following propositions are developed: 
Proposition 2a: The dialogue between FLEs and ISPs develop their knowledge sharing attitude

Proposition 2b: The access to resources between FLEs and ISPs develop their knowledge sharing attitude

Proposition 2c: The risk-assessment between FLEs and ISPs develop their knowledge sharing attitude

Proposition 2d: The transparency between FLEs and ISPs develop their knowledge sharing attitude

The responsive attitude is the propensity of the actors to effectively respond to the need of each actor. It is highly important for all actors to feel the responsibility of their duties and provide timely response to the other actor. The delay in response can create chaos for the actors which can create the feeling of value co-destruction instead of value co-creation. The usefulness of the four building blocks can create better responsive attitude. Thus, the following propositions are made:

Proposition 3a: The dialogue between FLEs and ISPs develop their responsive attitude

Proposition 3b: The access to resources between FLEs and ISPs develop their responsive attitude

Proposition 3c: The risk-assessment between FLEs and ISPs develop their responsive attitude

Proposition 3d: The transparency between FLEs and ISPs develop their responsive attitude

\subsection{Actors Value Co-Creation Attitude leads to Actors Value Co-Creation Behaviour}

The theory of attitude-behavior consistency explains the degree to which the attitudes (opinions) of the people predict their behavior (actions). Attitude-behavior consistency exists when there is a high relationship between opinions and actions (Haddock \& Maio, 2007). The behavior has a different explanation in different disciplines of the social sciences (Morris, Marzano, Dandy, \& O'Brien, 2012). In this context, the value co-creation behavior is defined as the actor's actual engagement in value co-creation (Laud \& Karpen, 2017). The value co-creation behavior promotes beneficial relationships among the actors (Laud \& Karpen, 2017). The value co-creation behavior is consists of two dimensions namely participation and citizenship behavior (Yi, Gong, \& Lee, 2013). The behavior of the actors is formed in response to the favorable attitude. For instance, if the ISPs fails to respond to the FLEs need, it may prevent the FLEs to further engage with ISPs for mutual value creation. Thus, despite of establishing a dialogue, the actual co-creation is not accomplished. As empirically proved, value co-creation attitude leads to value co-creation behaviour (Shamim 
et al., 2017), therefore, it is proposed that actors value co-creation attitude will significantly leads to actors value co-creation behavior in the context of a micro-level ecosystem. Hence, the following propositions are developed:

Proposition 4a: The actors' interaction attitude significantly develops their value co-creation behavior.

Proposition 4b: The actors' knowledge sharing attitude significantly develops their value co-creation behavior.

Proposition 4c: The actors' responsive attitude significantly develops their value co-creation behavior.

\section{Discussion and Conclusion}

This paper proposed the value co-creation practice at firms' micro-level eco-system where frontline employees' engagement in value co-creation with internal service providers is crucial. The paper proposed conceptual relationships between the building blocks of interaction, actors value co-creation attitude and behavior. The actors in this paper are the FLEs of the firm and the ISPs. The ISPs are the employees of all supporting departments such as production, warehousing, distribution, finance, human resources and others who are always keen to provide efficient service to the FLEs to ensure that FLEs can further provide service to the customers. The FLEs play dual roles whereby they interact with the actors at micro-level ecosystem within the firm as well as with the actors at meso and macro level ecosystem outside the firms. To ensure that FLEs co-creation value at micro-level, we propose the application of the DART model. The dialogue, access, risk-assessment and transparency between FLEs and ISPs can create their value co-creation attitude. Thus, they continually will engage with the ISPs and practice value co-creation at micro-level. The application of DART will also create ISPs value co-creation attitude; thus, they can also be the part of co-creation ecosystem as micro-level co-creation create ripple effect at meso and macro-level.

The practice of DART at micro-level create interaction attitude of FLEs with ISPs. The continuous interaction may lead to developing favorable co-creation attitude as an individual attitude may change as a result of the dialogue between two actors (Zorn, Roper, Weaver, \& Rigby, 2012). As the perceived organizational support is important for co-creation practice at micro-level (Yoo \& Arnold, 2015), the ISPs role in this context is considered as organizational support to the FLEs. The practice of the DART is deliberated to be an essential step and a valuable effort to value co-creation attitude of the actors (Mazur \& Zaborek, 2014). The actor's value co-creation attitude will further lead to value co-creation behavior (Shamim et al., 2017). Thus, the practice of value co-creation at micro-level ecosystem is attainable. 


\section{References}

Ajzen, I. (1991). The theory of planned behavior. Organizational Behavior and Human Decision Processes, 50(2), 179-211. doi:10.1016/0749-5978(91)90020-t

Albinsson, P. A., Perera, B. Y., \& Sautter, P. T. (2015). DART Scale Development: Diagnosing a Firm's Readiness for Strategic Value Co-creation. Journal of Marketing Theory and Practice, 24(1), 42-58. doi:10.1080/10696679.2016.1089763

Chaiklin, H. J. J. S., \& Welfare, S. (2011). Attitudes, behavior, and social practice. 38, 31.

Haddock, G., \& Maio, G. R. (2007). Encyclopedia of Social Psychology. Thousand Oaks, California: SAGE Publications, Inc. Retrieved from http://sk.sagepub.com/reference/socialpsychology. doi:10.4135/9781412956253

Holmes, J. D. (2009). Transparency of Self-Report Racial Attitude Scales. Basic and Applied Social Psychology, 31(2), 95-101. doi:10.1080/01973530902876884

Laud, G., \& Karpen, I. O. (2017). Value co-creation behaviour - role of embeddedness and outcome considerations'. Journal of Service Theory and Practice, 27(4), 778-807. doi:10.1108/Jstp-04-2016-0069

Lin, H. F., \& Lee, G. G. (2004). Perceptions of senior managers toward knowledge-sharing behaviour. Management Decision, 42(1), 108-125. doi:10.1108/00251740410510181

Mazur, J., \& Zaborek, P. (2014). Validating Dart Model. International Journal of Management and Economics, 44(1). doi:10.1515/ijme-2015-0012

Morris, J., Marzano, M., Dandy, N., \& O'Brien, L. (2012). Theories: Behaviour Change. Theories and models of behaviour and behaviour change.

Ostrom, T. M. (1969). The relationship between the affective, behavioral, and cognitive components of attitude. Journal of Experimental Social Psychology, 5(1), 12-30. doi:10.1016/0022-1031(69)90003-1

Prahalad, C., \& Ramaswamy, V. (2001). The value creation dilemma. Retrieved from

Prahalad, C. K., \& Ramaswamy, V. (2004a). Co-creation experiences: The next practice in value creation. Journal of Interactive Marketing, 18(3), 5-14. doi:10.1002/dir.20015

Prahalad, C. K., \& Ramaswamy, V. (2004b). Co-creating unique value with customers. Strategy \& Leadership, 32(3), 4-9. doi:10.1108/10878570410699249

Ramaswamy, V. (2005). Co-creating experiences with customers: new paradigm of value creation. The TMTC Journal of Management, 8, 6-14.

Russo Spena, T., Caridà, A., Colurcio, M., \& Melia, M. (2012). Store experience and cocreation: the case of temporary shop. International Journal of Retail \& Distribution Management, 40(1), 21-40. doi:10.1108/09590551211193586

Schiavone, F., Metallo, C., \& Agrifoglio, R. (2014). Extending the DART model for social media. International Journal of Technology Management, 66(4), 271-287. doi:10.1504/Ijtm.2014.064967

Shamim, A., \& Ghazali, Z. (2014). A conceptual model for developing customer value cocreation behaviour in retailing. Global Business and Management Research, 6(3), 185.

Shamim, A., Ghazali, Z., \& Albinsson, P. A. (2016). An integrated model of corporate brand experience and customer value co-creation behaviour. International Journal of Retail \& Distribution Management, 44(2), 139-158. doi:10.1108/Ijrdm-06-20150079

Shamim, A., Ghazali, Z., \& Albinsson, P. A. (2017). Construction and validation of customer value co-creation attitude scale. Journal of Consumer Marketing, 34(7), 591-602. doi:10.1108/Jcm-01-2016-1664 
Singh, J., Brady, M., Arnold, T., \& Brown, T. (2016). The Emergent Field of Organizational Frontlines. Journal of Service Research, 20(1), 3-11. doi:10.1177/1094670516681513

Solakis, K., Peña-Vinces, J. C., \& Lopéz-Bonilla, J. M. (2017). DART model from a customer's perspective: an exploratory study in the hospitality industry of Greece. Problems and Perspectives in Management, 15(si), 537-549. doi:10.21511/ppm.15(si).2017.07

Taghizadeh, S. K., Jayaraman, K., Ismail, I., \& Rahman, S. A. (2016). Scale development and validation for DART model of value co-creation process on innovation strategy. Journal of Business \& Industrial Marketing, 31(1), 24-35. doi:10.1108/Jbim-022014-0033

Vargo, S. L., Akaka, M. A., \& Vaughan, C. M. (2017). Conceptualizing Value: A Serviceecosystem View. Journal of Creating Value, 3(2), 117-124.

Vargo, S. L., \& Lusch, R. F. (2004). Evolving to a New Dominant Logic for Marketing. Journal of marketing, 68(1), 1-17. doi:10.1509/jmkg.68.1.1.24036

Vargo, S. L., \& Lusch, R. F. (2007). Service-dominant logic: continuing the evolution. Journal of the Academy of Marketing Science, 36(1), 1-10. doi:10.1007/s11747007-0069-6

Yi, Y., Gong, T., \& Lee, H. (2013). The Impact of Other Customers on Customer Citizenship Behavior. Psychology \& Marketing, 30(4), 341-356. doi:10.1002/mar.20610

Yi, Y., Nataraajan, R., \& Gong, T. (2011). Customer participation and citizenship behavioral influences on employee performance, satisfaction, commitment, and turnover intention. Journal of Business Research, 64(1), 88-96. doi:10.1016/j.jbusres.2009.12.007

Yoo, J., \& Arnold, T. J. (2015). Frontline Employee Customer-Oriented Attitude in the Presence of Job Demands and Resources. Journal of Service Research, 19(1), 102117. doi:10.1177/1094670515589956

Zorn, T. E., Roper, J., Weaver, C. K., \& Rigby, C. (2012). Influence in science dialogue: Individual attitude changes as a result of dialogue between laypersons and scientists. Public Underst Sci, 21(7), 848-864. doi:10.1177/0963662510386292 